\title{
Development of Automotive Vocational Homeschooling Education Based on Technopreneurship in Jakarta, Indonesia
}

\section{Siska Titik Dwiyati, Ahmad Kholil, Riyadi, and Ragil Sukarno}

Department of Mechanical Engineering Education, Faculty of Engineering, Universitas Negeri Jakarta, Indonesia

\section{Abstract}

The pattern of homeschooling learning time can be independently regulated and not be tied to the time to study like in a regular school. The Automotive vocational homeschooling designed with learning time independently is equivalent to Paket $\mathrm{C}$ so that graduates can continue to the college. The profile of graduates developed in automotive vocational homeschooling is entrepreneurship or implementing a car repair shop (service \& repair). Expertise is taken depending on the willingness and ability of students in following the learning process. Learning outcomes that have

Corresponding Author: Siska Titik Dwiyati siska.td@gmail.com

Received: 11 January 2019 Accepted: 14 February 2019 Published: 25 March 2019

Publishing services provided by Knowledge E

(c) Siska Titik Dwiyati et al. This article is distributed under the terms of the Creative Commons Attribution License, which permits unrestricted use and redistribution provided that the original author and source are credited.

Selection and Peer-review under the responsibility of the 3rd ICTVET 2018 Conference Committee.

\section{G OPEN ACCESS} been developed include: the ability to apply technopreneurship, basic automotive capabilities, car engine maintenance capabilities, chassis capability, capability of transfer power, and car electrical capability.

Keywords: automotive, homeschooling, vocational

\section{Introduction}

Homeschooling one of the informal education pathways that gives parents the freedom to provide appropriate learning patterns for their children in developing their talents and creativity. At present the students' need for vocational learning with time flexibility a driving force for the growth of alternative schools with vocational choices. Parents who want closeness with children in the midst of busyness want their children to master specific field skills so that one day they can become entrepreneurs, work on job or continue to University. It is just that it cannot obtained if you only study in general homeschooling. The previous results obtained that the factors supporting the idea of technopreneurship- based vocational homeschooling education that (1) there a positive enthusiasm from students to follow the learning process in homeschooling; (2) Very positive interest in homeschooling students to open their own business after graduation; (3) Many homeschooling students utilize technology for entrepreneurial opportunities; 
(4) Homeschooling students more interested in getting additional learning in the field of technopreneurship; and (5) hobbies favored by homeschooling students greatly facilitated by parents [1].

Homeschooling education model being favored by the Indonesian people, especially in the City [2]. The existing education model only meets the needs of public schools at the elementary, middle and high school levels [3]. One of the Indonesian Government's programs now to increase vocational education graduates through vocational education. At the regular vocational level there several skill groups such as cooking, cosmetology, beauty, automotive, machining, computer engineering, agriculture, and others. Learning carried out for three years with a curriculum that has regulated by the government through Permendikbud No. 24 of 2016. Parents who want their children to have skills than after junior high school will enter their children into regular vocational schools with a learning pattern that has arranged. Whereas parents who want their children to have skills but the pattern of learning time arranged independently cannot choose a regular vocational school. There no vocational homeschooling alternative options at the vocational level for student learning needs with flexible learning time settings. Homeschooling education in Indonesia managed by the Community Learning Activity Center (PKBM) with a range of learning activities level: Elementary School (Paket A), Junior High School (Paket B) and High School (Paket C). The existence of PKBM regulated and protected by the Government which ensures graduates of all programs can continue their education to a higher level, such as Paket $\mathrm{C}$ graduates can continue to universities or polytechnics [4].

National Education System Law (sidings) number 20 of 2003, article 27 paragraph 1 that informal education activities carried out by families and the environment takes the form of activities independently. While paragraph 2 that the results of informal education as referred to in paragraph (1) recognized as the same as formal and nonformal education after students pass the exam by national education standards. This proves that homeschooling recognized by the government. Legality recognized as the same as formal education because it can take the exam held by the Ministry of National Education through an equality test.

Homeschooling often called a homeschool or independent school, but there no specific definition of homeschooling because the model developed very diverse and varied [4]. The family chooses to take full responsibility for the child's education process with home-based. Homeschooling gives parents the freedom to provide learning patterns suitable for their children in developing talent and creativity [2]. Homeschooling can also be for children with special needs $[5,6]$. Homeschooling graduates equivalent 
to Paket $\mathrm{C}$, which a non-formal education pathway equivalent to high school (SMA) which facilitated by the Government for students who do not study through school channels. Paket $\mathrm{C}$ diplomas can continue to tertiary education, most of them accepted at universities in the country, and some accepted abroad. This reason makes parents choose to homeschool as an education for their children.

Entrepreneurial creation an alternative solution to various problems in society such as poverty and social inequality, increasing unemployment of productive age and depletion of reserves of energy supply, all of which require creative and innovative actions. The entrepreneurial spirit limited to not only academic intelligence and product-producing skills but also a dynamic soul in capturing challenges and risks then turning them into growth opportunities and potential [7]. Technopreneurship has the spirit to build a business that characteristically the integration of technology application competencies. The use of cutting-edge technology appropriate in the development of businesses based on an established entrepreneurial spirit will able to optimize the process as well as the results of the business units that developed [8]. Also, technopreneurship must successful in two ways, namely guaranteeing that the technology that becomes a business object can function according to needs, target customers and can sell to gain profits and provide benefits or impacts economically, socially and environmentally [9].

Homeschooling students who have a learning independence spirit, demanding creative and innovative actions because the learning system not likes regular schools [2]. They learn by utilizing the technology that around to learn science and skills such as the use of search menus on the internet to find learning resources [10]. By giving vocational curriculum to homeschooling students, students will interact more quickly with the environment in entrepreneurship learning. They will get data on business activities by interacting with business houses for business learning with a touch of technology gained in learning. For example, the parents of a beauty salon businessman want their children to able to continue their parents' efforts at some time. To continue the business, the child must have salon and management skills. To get these competencies, after graduating from junior high school, studying at a cosmetology vocational high school then continuing to study management so that it takes 6 to 7 years to achieve the desired competency. The approach to learning in regular schools more academic and has not able to reach maturity in conducting business independently because of the resolution of cases more theoretical. For this reason, it necessary to find solutions for parents of salon entrepreneurs to able to provide the best education for their children with an education that flexible learning time with a technopreneurship- based vocational 
curriculum. For that reason, parents enter their children into vocational homeschooling cosmetology education so that children can learn the theory of knowledge and technopreneurship from the teacher and the practice of vocational cosmetology with his parents' mentor as a salon entrepreneur. Theoretical learning more academic while the practice more real because it can work directly in the place of the business of his parents who also mentors. The use of technology in the workplace encourages the spirit to innovate in solving problems in the workplace even though it still under the guidance of parents. In three years competency has achieved because it has able to practice running a parlor business owned by parents and within three years it has also declared a high school equivalent with a Paket $C$. This diploma can used to continue management studies at universities for thinking maturity in running business parents. This idea is a challenge for alternative vocational homeschooling education in Indonesia. Whether existing homeschooling students support vocational homeschooling ideas [1].

\section{Research Purpose}

This study aims to develop the profile of graduates and learning outcomes of automotive vocational homeschooling based on technopreneurship that will be applied in Jakarta, Indonesia. The hope of this development can produce alternative education for people who want more flexible vocational education.

\section{Literature Review}

\subsection{Homeschooling education}

Homeschooling an alternative learning model other than in school, parents fully responsible, learning not always with parents as facilitators, the learning environment conducive and the goal that each child's unique potential develops maximally [2, 11]. Viewed from the positive side, homeschooling accommodates the child's potential intelligence optimally because each child has a variety and distinctiveness of different interests, talents, and skills. Also, it able to avoid negative influences that may be faced by public school children [12]. From a cynical perspective, it feared that children would alienated from their social environment so that their social intelligence potential does not arise. Homeschooling a proactive action to intervene in the education of our children and responsible for providing love for learning. So that parents can participate to supervise, encourage, explore and develop the potential of their children directly [13]. 
Homeschooling has several objectives [3], namely: (a) ensure the completion of quality primary and secondary education for students from children and families who choose homeschooling pathways; (b) ensuring equity and easy access to education for each for the process of academic learning and life skills; and (c) serving students who need flexible academic education and life skills to improve the quality of their education.

The reason parents choose homeschooling as education for their children is [3]:

1. Most parents want to have the opportunity to teach their children by choosing the education that contains elements of religious values and character as well as moral standards in the curriculum.

2. With homeschooling that has a tutorial learning system, which is one-on-one, parents can better meet their children's needs by supporting children's interests; each will value curiosity and every child.

3. Many think that children who study at homeschooling cannot socialize. It should note that the actual socialization is that children interact with various groups and different ages (vertical socialization), interactive children can not only measure with classmates or their peers in school (horizontal socialization). In homeschooling children are often better at interacting with people of various ages.

4. Through homeschooling, parents and children learn, explore, and spend time together. This will further strengthen the relationship between children and parents or siblings.

\subsection{Vocational education}

Elucidation of Article 15 of Law Number 20 of 2003 concerning the National Education System (National Education System Law) confirms that "Vocational Education is secondary education that prepares students especially to work in certain fields." Furthermore, in Article 36 paragraph (2) it is explained that "the curriculum at all levels and types of education developed with the principle of diversification by the education unit, regional potential, and students."

Working in a particular field as referred to in the National Education System Law above is undoubtedly by the types of occupations available in the employment field, either working independently or entrepreneurship or working on other parties. Therefore, the application of the principle of diversification in the development of the Vocational High School (SMK) Curriculum is realized by having to be oriented towards the types of work 
or expertise that are developed and needed in the world of work. The list of types of occupations or expertise in the vocational secondary education environment is known as the Vocational Secondary Education Skills Spectrum.

In order to adjust the curriculum with the characteristics of vocational education units, Minister of Education and Culture Regulation No. 70 of 2013 concerning the Basic Framework and Curriculum Structure of Vocational High Schools (SMK)/Vocational Madrasah Aliyah (MAK) which was later changed to the Minister of Education and Culture Regulation Number 60, Year 2014 concerning 2013 SMK/MAK Curriculum, the attachments related to the Curriculum Structure of SMK/MAK, among others, emphasized that in the determination of majors in accordance with the fields/programs/expertise packages consider the Vocational Secondary Education Skills Spectrum set by the Director General of Secondary Education Ministry of Education and Culture.

Based on the Minister of Education and Culture Regulation, the Decree of the Director General of Secondary Education Ministry of Education and Culture issued: 7013/D/KP/ 2013 concerning the Vocational Education Skills Spectrum. In this decision, it affirmed that spectrum as intended, is a reference in opening and organizing fields/programs/ packages of expertise at SMK/MAK. The skill spectrum of Vocational Secondary Education (PMK) is the types of educational programs as well as the implementation signs, as a reference in the opening and developing education programs at SMK/MAK.

The types of education programs in the Spectrum of Expertise organized in the form of Expertise Areas, Expertise Programs, and Expertise Packages. Equipped with the scope of competence for each Expertise Package.

1. Areas of expertise, is a collection of Expertise Programs that have similar characteristics and require the same primary field of study.

2. Expertise Program, is a collection of Expertise Packages that have the same characteristics of the basics of expertise/ work/tasks.

3. Expertise Package, is a unit of education and training program based on tasks in a particular position/job, with a duration of 3 or 4 years of secondary education unit. In each Expertise Package that is opened, Vocational Schools can specialize in specific competencies according to the demands of the related work world (concentration of expertise) by not ignoring the necessary skills of the relevant expertise.

The types of education programs in the Vocational High School are called the skill spectrum, because the departments that developed in the Vocational High School are 
the skills or job titles that exist and develop in the world of work, so it not based on discipline science. A job title or job title (job title) can be the result of focusing on some scientific disciplines.

\subsection{Technopreneurship concept}

Technology-based entrepreneurship or technopreneurship not the same as entrepreneurship in general. Entrepreneurship defined as a process of applying creativity and innovation in solving problems and finding opportunities to improve life [14]. A process of creativity and innovation that has a high risk to produce added value for products that benefit the community [15]. The technological entrepreneurship defined as entrepreneurial activities which involve technology in business. The use of research-based technology the advantage of higher education to develop technological entrepreneurship [16].

Technopreneurship a technology-based business/ incubator, this material model a breakthrough strategy to overcome the increasing problem of intellectual unemployment [17]. Entrepreneurship someone who creates a new business by taking the risk of uncertainty to achieve profits and growth by identifying opportunities and combining various resources [18]. Entrepreneurship the ability to create something new and different [19].

The entrepreneurial process begins with innovation [2]. These innovations influenced by various factors, both personal and outside personal, such as education, sociology, organization, culture, and environment [17]. These factors form the locus of control, creativity, innovation, implementation, and growth which then develop into large entrepreneurs [19].

Technopreneur a new age entrepreneur who interested in technology, creative, innovative, dynamic, dare to different and takes a path that has not explored and very passionate about his work. Technopreneur combines technology and markets, ultimately leading to business. They start a business based on technological innovation, must have some supporters including a strong desire to pursue achievement, conceptual ability, and high problem-solving power, have deep insight and way of thinking, high confidence, tolerance, risk-taking, realistic, interpersonal skills, and controlling emotions.

Various ways and models foster new technopreneur that thick with nuances of technological innovation including franchise models, partnership models, mentoring models, business incubator programs, and entrepreneurial education patterns in vocational 
schools developed by the government and non-government. The incubator program considered to have advantages because there will more professional new startups in the sense of being able to produce goods or services that more competitive. This possible because in the incubator program in educational institutions, startups educated to master all aspects of the business and equipped with facilities and working capital. With the incubator program, entrepreneurs who just starting their business supported by marketing, technical expertise, financing, and business management.

\section{Model Development of Automotive Vocational Homeschooling}

Determination of the automotive vocational homeschooling graduates are entrepreneurs and mechanic car repair shop (service \& repair). The car repair shop continues to grow and innovate along with the development of car technology. Homeschooling graduates will have Paket $\mathrm{C}$ certificate accompanied by a certificate for the car workshop entrepreneurship competency or a workshop implementer such as a mechanic. Paket $\mathrm{C}$ diploma is an acknowledgment of equal education with high school. While the certificate of expertise is obtained when achieving competency skills while attending vocational homeschooling education in automotive repair shops that are directed to become workshop entrepreneurs or become workshop executors such as mechanics. Expertise is taken depending on the willingness and ability of students to follow the learning process.

To achieve automotive vocational homeschooling expertise. Based on the graduate profile, the achievement of vocational homeschooling learning is determined by the automotive workshop. Learning outcomes, including: the ability to apply technopreneurship, basic automotive, car engine maintenance (service \& tune up), the selection of chassis, power transfer, and car electricity. The learning achievement was reduced back to the basic competencies of $\mathrm{C} 3$ and $\mathrm{C} 4$ levels. The following are the basic competencies developed:

1. Basic competence of technopreneurship

Level 3: $\quad 3.1$ Understand the basic principles of business

3.2 Describe the business feasibility study

3.3 Describe a business plan

3.4 Understanding marketing management

3.5 Describe business operations

3.6 Understanding human resource management 
3.7 Understand the product planning process

3.8 Understanding the product life circle strategy.

Level 4: $\quad 4.1$ Evaluating basic business principles

4.2 Prepare steps for business feasibility studies

4.3 Analyzing business plans

4.4 Evaluating marketing techniques and strategies

4.5 Analyze the product planning process

4.6 Analyzing workforce planning

4.7 Analyze the cost classification

\section{Basic automotive competencies}

Level 3: $\quad 3.1$ Understanding machine basics

3.2 Explain the meaning of statics and voltage

3.3 Describe techniques and principles for using manual technical drawing tools

3.4 Analyzing ISO standards regarding the layout of images and drawing paper layouts.

3.5 Understanding the types of lines and their use

3.6 Explain the purpose of occupational maintenance and safety

3.7 Understand the function of lubricating oil and grease

3.8 Understanding the basics of electricity

Level 4 : $\quad 4.1$ Applying the calculation of machine basics

4.2 Presenting techniques and principles for using manual technical drawing tools

4.3 Presenting standards regarding image layout and drawing paper layouts

4.4 Presenting a sketch of an object or object

4.5 Implementing OSH in accordance with $\mathrm{K} 3$ law, identifying security aspects and work procedures according to SOP

4.6 Implement fire extinguisher procedures according to fire classification.

4.7 Applying electricity basics

3. Basic competency of car engine maintenance (service, engine tune-up)

Level 3 : $\quad 3.1$ Understanding the engine mechanism

3.2 Understanding the engine cooling system

Level 4 : $\quad 4.1$ Maintaining the engine mechanism

4.2 Maintain the engine cooling system

4. Basic competency of chassis maintenance and car power transfer (repair/replace)

Level 3: $\quad 3.1$ Understanding wheels and tires 
3.2 Understanding the brake system

3.3 Understanding the wheel drive shaft

Level 4 : $\quad 4.1$ Maintain wheels and tires

4.2 Maintain the brake system

4.3 Maintain the wheel drive shaft

5. Basic competence of car electrical maintenance

Level 3 : $\quad 3.1$ Understanding the electrical system, safety and additional equipment

3.2 Understanding the battery

3.3 Understanding the ECU (Engine Control Unit)

Level 4: $\quad 4.1$ Maintaining the electrical system, safety and additional equipment in accordance with standard operating procedures (SOP)

4.2 Maintain batteries according to standard operating procedures (SOP)

4.3 Maintaining the ECU (Engine Control Unit) according to standard operating procedures (SOP)

\section{Conclusion}

The profile of graduates developed in automotive vocational homeschooling is entrepreneurship or implementing a car repair shop (service \& repair). Expertise is taken depending on the willingness and ability of students in following the learning process. Learning outcomes that have been developed include: the ability to apply technopreneurship, basic automotive capabilities, car engine maintenance capabilities, chassis capability, capability of transfer power, and car electrical capability.

\section{Acknowledgment}

The authors are thankful to the Head of LPPM UNJ for providing an opportunity to complete this research through PDUPT scheme, as well as to the Director of Research and Community Service of the Ministry of Research Technology and High Education for providing the research grant.

\section{References}

[1] Siska Titik Dwiyati, Ahmad Kholil, Riyadi, Ragil Sukarno. (2018). Vocational Homeschooling Educational Ideas Based on Technopreneurship in Jakarta Indonesia. Education, 8(4): 84-90. 
[2] Razi, Achmad. (2016) Homeschooling: an Alternative Education in Indonesia. International Journal of Nusantara Islam, Vol. 04 No. 02, pp: 75-84.

[3] Mulyadi, Seto. (2007). Homeschooling Keluarga Kak Seto: Mudah, Murah, Meriah dan Direstui Pemerintah. Jakarta: PT. Mizan Pustaka.

[4] Justisia and Fetty Fuji. (2011). Implementasi Pembelajaran Jarak Jauh di Lembaga Homeschooling Kak Seto (Studi Kasus di Lembaga Homeschooling Kak Seto Bandung). Skripsi. Bandung: Universitas Pendidikan Indonesia.

[5] Bambang Irawan, Agus Suryono and Ratih Nur Pratiwi, Sarwono. (2015). Model Implementation of Special Needs Education in Organizational Capacity Development Perspective (A Study on the Primary School Providers of Inclusion and Segregation for Autistic Students in Special Capital Region of Jakarta). International Journal of Applied Sociology, 5(3): 144-151.

[6] Maryam Soleimani and Najmousaddat Mousavi. (2016). The Effectiveness of Teachers in Regular Classes in the Process of Educating Students with Special Needs and Influencing Factors. Education, 6(2): 58-64.

[7] Edward, L.J and Muir, E.J. (2005) Promoting Entrepreneurship at The University of Glamorgan through Formal and Informal Learning. Journal of Small Business and Enterprise Development, 12,4; ABI/INFORM Global, Pg.613.

[8] Braunerhjelm, Pontus. (2010). Entrepreneurship, Innovation and Economic Growth Past experiences, current knowledge and policy implications. Research Network Debate Swedish Entrepreneurship Forum.

[9] Minniti, M., and Bygrave, W. (2001). A Dynamic Model of Entrepreneurial Learning. Entrepreneurship Theory and Practice, Spring.

[10] Mopangga, Herwin. (2015). Studi Kasus Pengembangan Wirausaha Berbasis Teknologi (Technopreneurship) di Provinsi Gorontalo. Jurnal Trikonomika Volume 14, No. 1, Hal. 13-24.

[11] Priyanka Y. Valhe, and Geeta Shinde. (2012). Alternative Education: Home Schooling, Scholarly Research Journal for Interdisciplinary Studies.

[12] Roache, Leo Ernest. (2009). Parental Choice and Education: The Practice of Homeschooling in New Zealand. A thesis of Doctor of Education at Massey University, Palmerston North.

[13] Neil, Ted., Bonner, Nancy., and Bonner, David. (2014). An Investigation of Factors Impacting The Use of Technology In A Home School Environment. Contemporary Issues In Education Research, Vol. 7, No. 2. 
[14] Sudarsih, Endang. (2013). Pendidikan Technopreneurship: Meningkatkan Daya Inovasi Mahasiswa Teknik dalam Berbisnis, Proceeding Seminar Nasional "Inovasi dan Technopreneurship" IPB.

[15] Jahani and Hady Efendy. (2017) Developing of Entrepreneurial Spirit in the Era of Asean Economic Community in Vocational High School. International Journal of Learning and Development, Vol. 7, No. 3.

[16] Suhartini, Yati. (2011). Analisis Faktor-Faktor Yang Mempengaruhi Minat Mahasiswa Dalam Berwiraswasta, (Studi Kasus Pada Mahasiswa Universitas PGRI Yogyakarta). Jurnal Akmenika UPY, Vol. 7.

[17] Kuratko, Donald F. (2004). Entrepreneurship Education in The 21st Century: From Legitimization to Leadership. A Coleman Foundation White Paper USASBE National Conference.

[18] Zimmerer and Scarborough. (2002). Pengantar Kewirausahaan dan Manajemen Bisnis Kecil. Jakarta: Prehallindo.

[19] Krueger, N. F. and A. L. Carsrud. (1993). Entrepreneurial intentions: applying the theory of planned behavior. Entrepreneurship \& Regional Development 5 (4): 315330. 